\title{
Dental conditions associated with preventable hospital admissions in Australia: a systematic literature review
}

\author{
Abhinav Acharya', Shahrukh Khan ${ }^{1 *} \mathbb{D}, \mathrm{Ha} \mathrm{Hoang}^{2}$, Silvana Bettiol ${ }^{3}$, Lynette Goldberg ${ }^{4}$ and Leonard Crocombe
}

\begin{abstract}
Background: Over the past two decades, there has been a decrease in dental diseases in Australia; however, the number of preventable dental hospital admissions has not diminished. This review reports on the factors associated with preventable dental hospital admissions in Australia.

Methods: A search of five databases was conducted using Medical subject headings/Emtree terms and Index terms. All original studies, published between January1965 and March 2018 in English, based on the Australian population, and examining the prevalence of oral conditions as a cause for emergency department presentations and hospital admissions were included. The mixed method appraisal tool was used to evaluate the included studies.

Results: Eleven cross-sectional studies met inclusion and exclusion criteria. All the studies, except one from Tasmania, were from Western Australia. The most common reasons for preventable dental hospital admissions were dental caries, followed by embedded or impacted teeth. Malignant neoplasms were reported as main causes of preventable dental hospital admissions in the older population.

Conclusions: Most studies on preventable dental hospital admissions were from one Australian state (Western Australia). Further research is required to determine the national prevalence and incidence of preventable dental hospital admissions. A periodic audit of preventable dental hospital admission data is needed for delivery of a fair and effective dental services.
\end{abstract}

Keywords: Hospitalisation, Oral health, Dental, Australia, Public health

\section{Background}

Potentially Preventable Hospital Admissions (PHA) are defined as conditions that could be avoided for hospitalisation if timely management and primary care had been provided [1]. PHA is a health system performance indicator of the accessibility to and effectiveness of primary health care, providing information on socioeconomic and racial disparities in access to primary health care, health inequalities and literacy, and the prevalence of health conditions in the community [1, 2]. Dental conditions, which are categorised as acute medical conditions, are one of the components of PHA according to the National

\footnotetext{
* Correspondence: Shahrukh.khan@utas.edu.au

${ }^{1}$ Centre for Rural Health, College of Health and Medicine, University of

Tasmania, Hobart, Tasmania, Australia

Full list of author information is available at the end of the article
}

Healthcare Agreement 2016 between the State and Commonwealth Governments of Australia [3].

There has been marked reductions in dental conditions in adults (tooth loss and dental decay) observed in two national surveys of adult oral health completed in 1987-88 and 200406 [4]. The reduction of dental caries in adults could be a result of reduction in tobacco consumption, adoption of better oral hygiene practices and public health interventions (water fluoridation and interventional procedures) [5], and provision of adult dental benefit schemes [6]. Time trend report suggests that dental caries experience among children 5-6 years and > 12 years declined significantly from 1970s until the late 1980s. However, the latest National Child Oral Health Survey (NCOHS) 2012-14 showed that the dental caries experience has been in fluctuation since 1987-88 survey, suggesting no

C The Author(s). 2018 Open Access This article is distributed under the terms of the Creative Commons Attribution 4.0 International License (http://creativecommons.org/licenses/by/4.0/), which permits unrestricted use, distribution, and 
serious decline in the dental caries experience in between the two time points [7].

In contrast to the above findings, the Preventable Dental Hospital Admissions (PDHA) have not diminished. Dental conditions contribute to $9 \%$ of total PHA in Australia [8]. There were 57,955 cases of dental conditions leading to PHA in 2007-2008, which had increased to 63,456 in 2013-2014 [9].

Hence, to develop a sound understanding of dental causes that contributes towards PDHA, it is important to map the factors that may lead to preventable PDHA in the Australian population. This study aimed to synthesise the literature on the factors that lead to PDHA in Australia. This review will assist policy makers and oral health practitioners to understand the causes of PDHA and find methods to prevent PDHA, thereby reducing costs associated with PDHA.

\section{Methodology}

\section{Review question}

The Population Intervention Comparator Outcome (PICO) criteria and the Preferred Reporting Items for Systematic Reviews and Meta-Analyses (PRISMA) guidelines were used to devise and construct the review question. The review question was "What are the main causes of PDHA in Australia?"

\section{Scope of review and search terms}

Published results of studies examining the prevalence of oral / dental conditions as a cause for emergency department presentations and hospital admissions were reviewed. Articles were retrieved using searches performed in PubMed/MEDLINE, EMBASE, Web of Science, CINAHL and Google Scholar. The search terms used in the review were generated using the National Library of Medicine Medical Subject Headings (MeSH) terms, Emtree terms and free text terms. Table 1 shows the search terms used in the systematic review.

\section{Inclusion and exclusion criteria}

All original studies addressing the research question, published between January 1965 and March 2018 in English and based on the Australian population, including both adults and children, were included in the review. Studies were excluded if they were conducted outside Australia or were reviews, conference papers, short communications, letters or textbooks.

\section{Quality appraisal}

The Mixed Method Appraisal Tool (MMAT) was used for quality appraisal of the selected articles [10]. All of the articles included in the study were cross sectional studies, which fall under quantitative non-randomised study. Two independent reviewers (A.A. and H.H.) assessed the six criteria designed to evaluate the quality of methodology and overall quality score was calculated. All of the articles fulfilled methodological quality criteria as per MMAT. Table 2 shows the criteria and the summary of MMAT.

\section{Results}

\section{Selection of studies}

The literature search and removal of duplicates identified 1856 papers as eligible for inclusion in the review. These studies underwent title and abstract screening independently by two reviewers (A.A and S.K), resulting in selection of 86 studies for full text review. After the full text review, 11 studies met the inclusion and exclusion criteria and were included in the table of synthesis (Table 3). The PRISMA diagram shows the flowchart of selection of studies in the systematic review (Fig. 1).

\section{Study characteristics}

All the studies were from Western Australia (WA) except one study, which was based in Tasmania [11]. Of all the studies, there was one study on age ranges $0-2$ years [12], two among $0-5$ years $[13,14]$, one in $0-14$ years [15], two in $0-17$ years $[16,17]$, two in 18 years and above $[18,19]$, one in 65 years and above [20] and two from all age groups [11, 21]. All studies were cross-sectional analysis.

Of the WA studies, six used data from Western Australian Hospital Morbidity Data System (WAHMDS) [15, 16, 18-21]. Two used data collectively from multiple sources: WAHMDS, WA Maternal and Child Health Database for children born in WA, and the WA Intellectual Disability Database and Midwives Notification System Registrar General Database [13, 14]. One study used data from WAHMDS, WA Maternal and Child Health Database for children, and WA Intellectual Disability Database [12]. One used data from the Health Department of WA database [17]. The study in Tasmania has reported on patients presenting with dental conditions to the Emergency Department of the Royal Hobart Hospital [11].

In all studies except one [11], the definition used to identify the PDHA was based on the International Classification of Diseases (ICD), however the ICD versions varied across the studies based on the year published and the update of the classification. Four used ICD $9[12-14,17]$, and six used ICD 10 [15, 16, 18-21]. The Tasmanian study did not report the classification system used to identify the dental causes stating that patients were allocated a code referring to their main complaint [11].

\section{Dental reasons for PHA}

Five out of the eleven studies included in the review identified diseases of the hard tissues of teeth particularly dental caries as the most common cause leading to PDHA in the Australian population [12-15, 21]. The second most common cause of PDHA, reported in three studies, was embedded and impacted teeth $[16,18,19]$. One study listed both dental caries and embedded and impacted teeth as the main cause of PDHA [17]. Malignant neoplasms were reported as main causes of PDHA in one study which investigated PDHAs in the older population [20]. In the Tasmanian study, dental abscesses were the main causes of PDHA [11]. 
Table 1 Search Terms

\begin{tabular}{|c|c|c|}
\hline $\begin{array}{l}\text { Mesh Terms for oral } \\
\text { conditions }\end{array}$ & Free text terms & $\begin{array}{l}\text { Mesh terms for } \\
\text { Hospitalization }\end{array}$ \\
\hline Periodontal disease & Dental condition & Hospitalization \\
\hline Periodontitis & Oral Condition & Institutionalization \\
\hline Chronic Periodontitis & Adult Periodontitis & $\begin{array}{l}\text { Preventable } \\
\text { hospitalization }\end{array}$ \\
\hline $\begin{array}{l}\text { Temporomandibular Joint } \\
\text { Disorders }\end{array}$ & Dental abscess & Emergency service \\
\hline Dental caries & Oral abscess & Emergency Medicine \\
\hline Jaw fracture & TMJ Diseases & $\begin{array}{l}\text { Emergency Medical } \\
\text { Services }\end{array}$ \\
\hline Mandibular fracture & TMJ Disorders & Patient admission \\
\hline Maxillary fracture & $\begin{array}{l}\text { Temporomandibular } \\
\text { Disorder }\end{array}$ & Patient readmission \\
\hline Maxillofacial injuries & Oral cancer & Emergencies \\
\hline Facial injuries & $\begin{array}{l}\text { Oral squamous cell } \\
\text { carcinoma }\end{array}$ & First Aid \\
\hline Mouth Diseases & Tooth decay & Crisis Intervention \\
\hline Halitosis & Dental decay & ER \\
\hline Pulpitis & Tooth pain & Hosp \\
\hline Tooth Avulsion & Dental pain & ED \\
\hline Facial Nerve Diseases & Tooth fracture & Emergency Department \\
\hline Trigeminal Nerve Diseases & Dental fracture & Length of stay \\
\hline Facial Neuralgia & Maxillofacial injury & Emergency \\
\hline Lingual Nerve Injuries & Oral diseases & \\
\hline Mouth Neoplasms & Oral Manifestations & \\
\hline Oral Fistula & Oral health & \\
\hline Oral Ulcer & $\begin{array}{l}\text { Endodontic } \\
\text { Inflammation }\end{array}$ & \\
\hline Oral Submucous Fibrosis & Pulpitides & \\
\hline Ranula & Endodontic infection & \\
\hline Salivary gland Diseases & Tooth Avulsions & \\
\hline Xerostomia & Facial Nerve Injury & \\
\hline Stomatitis & Facial Nerve Trauma & \\
\hline Tongue diseases & $\begin{array}{l}\text { Facial Neuropathy, } \\
\text { Traumatic }\end{array}$ & \\
\hline Oral Tuberculosis & Cranial Nerve VII Injuries & \\
\hline Glossitis & Facial Nerve Avulsion & \\
\hline Hairy Tongue & Tooth Luxation & \\
\hline Tongue Neoplasms & Avulsed Tooth & \\
\hline Sialadenitis & Tooth Luxation & \\
\hline Aphthous Ulcers & Tooth Dislocation & \\
\hline Herpetic Stomatitis & Dental implant failure & \\
\hline \multicolumn{3}{|l|}{ Denture Stomatitis } \\
\hline \multicolumn{3}{|l|}{ Peri-implantitis } \\
\hline \multicolumn{3}{|l|}{ Root caries } \\
\hline Dental Fluorosis & & \\
\hline
\end{tabular}

\section{Demographic factors}

Additional factors that accounted for PDHA were indigenous population and aboriginal status [14, 18, 20], children living in areas without water fluoridation [13], people with intellectual disability [12-14], and children of indigenous mothers [13], individuals on public funded assistance [14], remoteness and rural residence $[12,16]$ (Table 3$)$.

\section{Discussion}

A total of 11 studies were included in this systematic review designed to map the PDHA in the Australian population. Other than the study in Tasmania [11], all the studies were from one state in Australia, WA. This indicates that further research is needed to ascertain the PDHAs across all states and territories of Australia to understand the causes of PDHA, and to find methods to prevent PDHA thereby reducing costs associated with PDHA.

The most common reasons for PDHA across age ranges were dental caries followed by embedded or impacted teeth. Prevention of embedded or impacted teeth is difficult and treatment focuses on their identification and removal. Unfortunately, incidence of impacted teeth may increase as fewer teeth are lost from dental diseases. Preventively however, the high incidence of PDHA for dental caries is a concern. Proper oral hygiene, low sugar consumption, fluoride applications and routine dental visiting are strategies to prevent dental caries [22]. In addition, other preventative strategies recommended by the World Health Organisation [23] include water fluoridation, using fluoride toothpaste and salt fluoridation. There is a need to better prevent and reduce the incidence of dental caries as this will ultimately help to decrease PDHA.

In Australia the prevalence of dental caries is $25.5 \%$ in adults and $45-60 \%$ in children [24]. Low education, low income, rural location, having no insurance, risk behaviours such as smoking and alcohol, poor dental visiting behaviour and oral hygiene practices, and no fluoride in water are important risk factors associated with dental caries and, if not addressed, subsequent hospitalisation [25]. Similar findings have been reported in New Zealand. In a 20-year review of potentially preventable admissions to public hospitals for dental care, data suggest that dental caries is the most common cause for PDHA in New Zealand [26].

A preventable hospital admission is a measure of health care accessibility and effectiveness [3]. Hospital admissions due to dental conditions indicate the burden of dental conditions and their associated costs on the health care system [19]. Strategies that could reduce PDHA include (i) preventive dental practices such as water fluoridation and interventional procedures (fissure sealants and fluoride varnish) in public and private healthcare settings [27]; (ii) improved and better access to dental care (child and adult dental benefit schemes) across urban, rural and remote communities [6]; and (iii) oral health literacy and education programs across the population with the use of social media, education and primary health care network platforms. Figure 2 illustrates the schematic representation of risk factors and preventive strategies to prevent PDHAs. 
Table 2 Quality appraisal of studies using Mixed Method Appraisal Tool

\begin{tabular}{|c|c|c|c|c|c|c|c|}
\hline $\begin{array}{l}\text { Author } \\
\text { and year }\end{array}$ & $\begin{array}{l}\text { Are there } \\
\text { clear } \\
\text { quantitative } \\
\text { research } \\
\text { questions } \\
\text { (objectives)? }\end{array}$ & $\begin{array}{l}\text { Do the } \\
\text { collected } \\
\text { data address } \\
\text { the research } \\
\text { question } \\
\text { (objective)? }\end{array}$ & $\begin{array}{l}\text { Are } \\
\text { participants } \\
\text { recruited in a } \\
\text { way that } \\
\text { minimises } \\
\text { selection } \\
\text { bias? }\end{array}$ & $\begin{array}{l}\text { Are } \\
\text { measurements } \\
\text { appropriate } \\
\text { regarding the } \\
\text { exposure/ } \\
\text { intervention and } \\
\text { outcomes? }\end{array}$ & $\begin{array}{l}\text { In the groups being } \\
\text { compared, are the } \\
\text { participants comparable, or } \\
\text { do researchers take into } \\
\text { account the difference } \\
\text { between the groups? }\end{array}$ & $\begin{array}{l}\text { Are there complete outcome } \\
\text { data ( } 80 \% \text { or above), or an } \\
\text { acceptable follow-up rate for } \\
\text { cohort studies (depending on } \\
\text { the duration of follow up)? }\end{array}$ & $\begin{array}{l}\text { Overall } \\
\text { quality } \\
\text { score }\end{array}$ \\
\hline $\begin{array}{l}\text { Tennant } \\
\text { et.al., } \\
2000 \text { [16] }\end{array}$ & yes & yes & yes & yes & yes & yes & 1 \\
\hline $\begin{array}{l}\text { Smith } \\
\text { et.al, } 2006 \\
{[17]}\end{array}$ & yes & yes & yes & yes & yes & yes & 1 \\
\hline $\begin{array}{l}\text { Kruger } \\
\text { et.al, } 2006 \\
{[15]}\end{array}$ & yes & yes & yes & yes & yes & yes & 1 \\
\hline $\begin{array}{l}\text { Slack- } \\
\text { Smith } \\
\text { et.al, } 2008 \\
\text { [12] }\end{array}$ & yes & yes & yes & yes & yes & yes & 1 \\
\hline $\begin{array}{l}\text { Slack- } \\
\text { Smith } \\
\text { et.al, } 2011 \\
\text { [13] }\end{array}$ & yes & yes & yes & yes & yes & yes & 1 \\
\hline $\begin{array}{l}\text { Slack- } \\
\text { Smith } \\
\text { et.al, } 2012 \\
\text { [11] }\end{array}$ & yes & yes & yes & yes & yes & Yes & 1 \\
\hline $\begin{array}{l}\text { Verma } \\
\text { et.al, } 2014 \\
\text { [10] }\end{array}$ & yes & yes & yes & yes & yes & Yes & 1 \\
\hline $\begin{array}{l}\text { Alsharif } \\
\text { et.al,2014 } \\
{[14]}\end{array}$ & yes & yes & yes & yes & yes & Yes & 1 \\
\hline $\begin{array}{l}\text { Kruger } \\
\text { et.al, } 2015 \\
{[20]}\end{array}$ & yes & yes & yes & yes & yes & Yes & 1 \\
\hline $\begin{array}{l}\text { Kruger } \\
\text { et.al, } 2016 \\
\text { [19] }\end{array}$ & yes & yes & yes & yes & yes & Yes & 1 \\
\hline $\begin{array}{l}\text { Kruger } \\
\text { et.al, } 2016 \\
{[18]}\end{array}$ & yes & yes & yes & yes & yes & Yes & 1 \\
\hline
\end{tabular}

In the Tasmanian study, dental abscesses were the main causes of PDHA [11]. This makes sense because this study investigated dental emergencies presenting to a Royal Hobart hospital emergency department, where people could be expected to present with pain or infections. Important to note was that $68 \%$ of all the presentations to the emergency department were after hours, when dentists are unavailable. Hence it is important to consider an after hour dental service for any emergency dental presentation.

Malignant neoplasms were reported as a leading causes of PDHA in the older population in one of the studies [20]. This also does not come as a surprise because the research in this study was limited to people over the age of 65 , the age group with the highest incidence of neoplasms [28, 29].
PDHA were higher in indigenous population and aboriginal status $[14,18,20]$. Low education, lower annual income, rural and remote location, having no dental insurance, poor access to care, lack of transportation and unemployment are the associated factors with indigenous people [24]. As oral conditions are associated with systemic health conditions such as obesity and cardiovascular disease, unawareness of maintaining proper oral health by socially disadvantaged people might have negative impacts on their general health [30,31]. This study will help policy makers to prioritise the preventive approach to address the oral health of socially disadvantaged groups and consequently minimise the PDHA among this group. 
Table 3 Characteristics of studies and the summary of results

\begin{tabular}{|c|c|c|c|c|c|c|}
\hline \multirow{2}{*}{$\begin{array}{l}\text { Author, year, } \\
\text { state }\end{array}$} & \multirow{2}{*}{$\begin{array}{l}\text { Number of } \\
\text { hospitalised } \\
\text { episodes/ } \\
\text { age }\end{array}$} & \multirow{2}{*}{$\begin{array}{l}\text { Classification } \\
\text { for diagnosis } \\
\text { of disease }\end{array}$} & \multirow[t]{2}{*}{ Study design } & \multirow[t]{2}{*}{ Covariates } & \multicolumn{2}{|l|}{ Summary of results } \\
\hline & & & & & $\begin{array}{l}\text { Reason for } \\
\text { hospitalisation }\end{array}$ & Demographic factors \\
\hline $\begin{array}{l}\text { Tennant et.al., } \\
2000[16] \\
\text { WA }\end{array}$ & $\begin{array}{l}N=3754 \\
\text { Age (0-17 } \\
\text { Years) } \\
\text { 1. Infant (0- } \\
\text { 1y) } \\
\text { 2. Preschool } \\
\text { (1-4yrs) } \\
\text { 3. Primary } \\
\text { school (5- } \\
\text { 12 yrs) } \\
\text { 4. High } \\
\text { school (13- } \\
17 y r s)\end{array}$ & $\begin{array}{l}\text { ICD } 9 \\
\text { [mentioned as } \\
\text { ICD (5200- } \\
5299)]\end{array}$ & $\begin{array}{l}\text { Cross } \\
\text { sectional } \\
\text { Retrospective }\end{array}$ & $\begin{array}{l}\text { Aboriginality, Residency } \\
\text { (rural and metropolitan), } \\
\text { Age, Gender }\end{array}$ & $\begin{array}{l}\text { Dental caries was the } \\
\text { primary reason for } \\
\text { hospitalisation in } \\
\text { preschool and } \\
\text { primary school } \\
\text { children. } \\
\text { Abnormal tooth } \\
\text { eruption was the } \\
\text { primary reason for } \\
\text { hospitalisation in high } \\
\text { school children. }\end{array}$ & $\begin{array}{l}\text { Out of total hospitalised } \\
\text { cases, } \\
\text { - } 0.6 \% \text { were infants, } \\
\text { - } 22.3 \% \text { pre-schoolers, } \\
\text { - } 25.7 \% \text { primary school } \\
\text { children and } \\
\text { - } 51.5 \% \text { high school children. } \\
\text { Males ( } 44 \% \text { ) and non- } \\
\text { Aboriginal decent ( } 98 \% \text { ) were } \\
\text { main groups for dental re- } \\
\text { lated hospital admissions } \\
\text { Non-aboriginal high school } \\
\text { children and infants had } \\
\text { higher hospitalisation due to } \\
\text { oral condition as compared } \\
\text { to Aboriginals. } \\
\text { Rural child had } 1.3 \text { times } \\
\text { higher risk of hospitalisation } \\
\text { due to dental condition as } \\
\text { compared to metropolitan. }\end{array}$ \\
\hline
\end{tabular}

\begin{tabular}{|c|c|c|c|c|c|c|}
\hline $\begin{array}{l}\text { Smith et.al, } \\
2006[17] \\
\text { WA }\end{array}$ & $\begin{array}{l}N=53,646 \\
\text { Age Adult } \\
\text { population } \\
\text { (18-85+ } \\
\text { years) }\end{array}$ & ICD- $10 \mathrm{AM}$ & $\begin{array}{l}\text { Cross } \\
\text { sectional } \\
\text { Retrospective }\end{array}$ & $\begin{array}{l}\text { Age, Indigenous status, } \\
\text { Residency (rural and } \\
\text { metropolitan), IRSD, ARIA }\end{array}$ & $\begin{array}{l}\text { The prevalence of } \\
\text { hospital admissions } \\
\text { due to oral conditions } \\
\text { were: } \\
\text { - Embedded and } \\
\text { impacted teeth } \\
\text { (38.8\%) } \\
\text { - Dental caries (8\%). } \\
\text { After excluding } \\
\text { embedded and } \\
\text { impacted teeth the } \\
\text { main reason for } \\
\text { hospitalisations were } \\
\text { - Dental caries } \\
\text { - Maxillary sinusitis } \\
\text { - Malignant } \\
\text { neoplasms (oral } \\
\text { related) } \\
\text { - Disorders of teeth } \\
\text { and supporting } \\
\text { structures. }\end{array}$ & $\begin{array}{l}\text { Female (52.2\%) were more } \\
\text { hospitalised than male. } \\
\text { Most common reason for } \\
\text { hospitalisation with age } \\
\text { - Individuals less than } 35 \\
\text { years - gingivitis and } \\
\text { periodontal diagnosis, } \\
17.5 \% \\
\text { - Individuals } 35 \text { years and } \\
\text { older- malignant } \\
\text { neoplasms, } 14.5 \% \\
\text { Indigenous Australians were } \\
\text { admitted } 1.5 \text { times more in } \\
\text { hospital for oral health } \\
\text { conditions ( } p \leq 0.05 \text { ). } \\
\text { Least disadvantaged people } \\
\text { ( } p \leq 0.05) \text { and highly } \\
\text { accessible people }(p \leq 0.05 \text { ) } \\
\text { were more likely to be } \\
\text { hospitalised due to oral } \\
\text { health related conditions. }\end{array}$ \\
\hline $\begin{array}{l}\text { Kruger et.al, } \\
2006 \text { [15] } \\
\text { WA }\end{array}$ & $\begin{array}{l}N=26,497 \\
\text { Age }(0-17 \\
\text { Years }) \\
\text { 1. } 0-1 y \\
\text { 2. } 1-4 \mathrm{yrs} . \\
\text { 3. } 5-12 \mathrm{yrs} . \\
\text { 4. } 13-17 \mathrm{yrs}\end{array}$ & ICD- 10 AM & $\begin{array}{l}\text { Cross } \\
\text { sectional } \\
\text { Retrospective }\end{array}$ & $\begin{array}{l}\text { Age, Aboriginality, Residency, } \\
\text { Gender, }\end{array}$ & $\begin{array}{l}\text { The reasons for } \\
\text { hospitalisation were } \\
\text { - Embedded and } \\
\text { Impacted teeth - } \\
33.2 \% \\
\text { - Dental Caries- } 28.3 \% \\
\text { - Pulp and peri-apical } \\
\text { tissues - } 7.1 \% \\
\text { - Dental facial } \\
\text { anomalies - } 6.1 \% \\
\text { - Birth trauma and } \\
\text { congenital } \\
\text { deformities }-4.1 \%\end{array}$ & $\begin{array}{l}\text { Out of total oral condition } \\
\text { related hospital admission } \\
\text { cases, } 50.2 \% \text { were male and } \\
3.5 \% \text { were aboriginal } \\
\text { descent. } \\
\text { The number of } \\
\text { hospitalisation was more in } \\
\text { rural aboriginal children as } \\
\text { compared to urban non } \\
\text { aboriginals. }\end{array}$ \\
\hline $\begin{array}{l}\text { Slack-Smith } \\
\text { et.al, } 2008 \text { [12] } \\
\text { WA }\end{array}$ & $\begin{array}{l}N=11,523 \\
\text { Age }(0-5 \\
\text { years })\end{array}$ & ICD - 9 & $\begin{array}{l}\text { Cross } \\
\text { sectional } \\
\text { Retrospective }\end{array}$ & $\begin{array}{l}\text { Age, Sex, Birth weight, year } \\
\text { of birth, SEIFA, Health } \\
\text { insurance, Health region, } \\
\text { Rurality, Maternal age group, } \\
\text { Mother's Indigenous status, } \\
\text { Intellectual disability, Birth } \\
\text { defect }\end{array}$ & $\begin{array}{l}\text { The reasons for } \\
\text { hospitalisation were } \\
\text { - Disease of hard } \\
\text { tissues of teeth } \\
76.3 \% \text {, } \\
\text { - Disorders of tooth } \\
\text { development and } \\
\text { eruption } 3.7 \% \\
\text { - Diseases of pulp and } \\
\text { periapical tissues }\end{array}$ & $\begin{array}{l}\text { Children ( } 0-5 \text { years) } \\
\text { accounted } 3 \% \text { of total dental } \\
\text { hospital admission. } \\
\text { Logistic regressions showed } \\
\text { significantly higher } \\
\text { hospitalisation among } \\
\text { children }(p<0.05) \text { with } \\
\text { - birth defect (OR 1.85, Cl } \\
\text { 1.68-2.05), } \\
\text { - Male gender, (OR 1.16, Cl }\end{array}$ \\
\hline
\end{tabular}


Table 3 Characteristics of studies and the summary of results (Continued)

\begin{tabular}{|c|c|c|c|c|c|c|}
\hline \multirow{2}{*}{$\begin{array}{l}\text { Author, year, } \\
\text { state }\end{array}$} & \multirow{2}{*}{$\begin{array}{l}\text { Number of } \\
\text { hospitalised } \\
\text { episodes/ } \\
\text { age }\end{array}$} & \multirow{2}{*}{$\begin{array}{l}\text { Classification } \\
\text { for diagnosis } \\
\text { of disease }\end{array}$} & \multirow[t]{2}{*}{ Study design } & \multirow[t]{2}{*}{ Covariates } & \multicolumn{2}{|l|}{ Summary of results } \\
\hline & & & & & $\begin{array}{l}\text { Reason for } \\
\text { hospitalisation }\end{array}$ & Demographic factors \\
\hline & & & & & $\begin{array}{l}10 \% \\
\text { - Gingival and } \\
\text { periodontal diseases } \\
1 \% \\
\text { - Dentofacial } \\
\text { anomalies including } \\
\text { malocclusion } 0.2 \% \\
\text { - Other diseases and } \\
\text { conditions of the } \\
\text { teeth and } \\
\text { supporting } \\
\text { structures } 0.7 \% \\
\text { - Diseases of the jaws } \\
0.4 \% \\
\text { - Diseases of the } \\
\text { salivary glands } 1.2 \% \\
\text { - Diseases of the oral } \\
\text { soft tissues } \\
\text { excluding lesions } \\
\text { specific } \\
\text { - for gingiva and } \\
\text { tongue } 5.4 \% \\
\text { - Diseases and other } \\
\text { conditions of the } \\
\text { tongue } 0.3 \% \\
\text { - Fitting devices and } \\
\text { special investigations } \\
1 \%\end{array}$ & $\begin{array}{l}\text { 1.08-1.25), } \\
\text { - Indigenous mother (OR } \\
\text { 1.17, Cl 1.02-1.34), } \\
\text { - No water fluoridation (OR } \\
\text { 2.16, Cl 1.94-2.40) } \\
\text { - Intellectual disability, } \\
\text { - privately funded health } \\
\text { insurance }\end{array}$ \\
\hline $\begin{array}{l}\text { Slack-Smith } \\
\text { et.al, } 2011 \text { [13] } \\
\text { WA }\end{array}$ & $\begin{array}{l}N=738 \\
\text { Age }(0-5 \\
\text { years })\end{array}$ & $\begin{array}{l}\text { ICD-9, } \\
\text { (ICD-10 AM } \\
\text { was converted } \\
\text { to ICD-9 for in- } \\
\text { dividuals ad- } \\
\text { mitted after 1- } \\
\text { 07-1999). }\end{array}$ & $\begin{array}{l}\text { Cross } \\
\text { sectional } \\
\text { Retrospective }\end{array}$ & $\begin{array}{l}\text { Indigenous status, Age, ARIA, } \\
\text { Length of stay }\end{array}$ & $\begin{array}{l}\text { Main causes of dental } \\
\text { admission were: } \\
\text { - Disorders of tooth } \\
\text { development and } \\
\text { eruption } 4.16 \% \\
\text { - Diseases of hard } \\
\text { tissues of teeth } \\
37.67 \% \\
\text { - Diseases of pulp and } \\
\text { periapical tissues } \\
10.98 \% \\
\text { - Gingival and } \\
\text { periodontal diseases } \\
5.28 \% \\
\text { - Other diseases and } \\
\text { conditions of the } \\
\text { teeth and } \\
\text { supporting } \\
\text { structures } 0.14 \% \\
\text { - Diseases of the jaws } \\
\text { 0.54\% } \\
\text { - Diseases of the } \\
\text { salivary glands } 2.57 \% \\
\text { - Diseases of the oral } \\
\text { soft tissues } \\
\text { excluding lesions } \\
\text { specific } \\
\text { - for gingiva and } \\
\text { tongue } 35.64 \% \\
\text { - Diseases and other } \\
\text { conditions of the } \\
\text { tongue } 1.22 \% \\
\text { - Fitting devices and } \\
\text { special investigations } \\
0.81 \% \\
\text { - Dental examination } \\
0.54 \%\end{array}$ & $\begin{array}{l}3.2 \% \text { of indigenous children } \\
\text { had dental related hospital } \\
\text { admission as compared to } \\
2.7 \% \text { non-indigenous } \\
\text { children. } \\
\text { Indigenous children had } \\
\text { more dental related hospital } \\
\text { admission at age less than } 2 \\
\text { years as compared to non- } \\
\text { indigenous children. (40\% } \\
\text { versus } 10 \%, P<0.0001) \text {. } \\
6.3 \% \text { of total dental related } \\
\text { hospital admission were } \\
\text { indigenous children. } \\
\text { Out of total indigenous } \\
\text { children dental admission, } \\
8.7 \% \text { had birth defect and } \\
5.5 \% \text { had intellectual } \\
\text { disability. } \\
\text { Length of stay (7 days or } \\
\text { more) in hospital was } \\
\text { recorded higher in } \\
\text { indigenous versus non- } \\
\text { indigenous children (11.2\% } \\
\text { versus } 0.5 \%, P<0.001) \text {. } \\
\text { Remoteness (OR 2.07 versus } \\
1.05 \text { ), public funded } \\
\text { assistance (89\% versus } 44 \% \text { ), } \\
\text { rural residence (OR } 9.61 \\
\text { versus } 1.48 \text { ) were significantly } \\
\text { associated factors with } \\
\text { dental related hospital } \\
\text { admissions in Indigenous } \\
\text { children versus non- } \\
\text { indigenous children. }\end{array}$ \\
\hline
\end{tabular}


Table 3 Characteristics of studies and the summary of results (Continued)

\begin{tabular}{|c|c|c|c|c|c|c|}
\hline \multirow{2}{*}{$\begin{array}{l}\text { Author, year, } \\
\text { state }\end{array}$} & \multirow{2}{*}{$\begin{array}{l}\text { Number of } \\
\text { hospitalised } \\
\text { episodes/ } \\
\text { age }\end{array}$} & \multirow{2}{*}{$\begin{array}{l}\text { Classification } \\
\text { for diagnosis } \\
\text { of disease }\end{array}$} & \multirow[t]{2}{*}{ Study design } & \multirow[t]{2}{*}{ Covariates } & \multicolumn{2}{|l|}{ Summary of results } \\
\hline & & & & & $\begin{array}{l}\text { Reason for } \\
\text { hospitalisation }\end{array}$ & Demographic factors \\
\hline $\begin{array}{l}\text { Slack-Smith } \\
\text { et.al, } 2012[11] \\
\text { WA }\end{array}$ & $\begin{array}{l}N=1513 \\
0-2 \text { years }\end{array}$ & $\begin{array}{l}\text { ICD-9 } \\
\text { (ICD-10 AM } \\
\text { was converted } \\
\text { to ICD-9 for in- } \\
\text { dividuals ad- } \\
\text { mitted after 1- } \\
\text { 07-1999). }\end{array}$ & $\begin{array}{l}\text { Cross } \\
\text { sectional } \\
\text { Retrospective }\end{array}$ & $\begin{array}{l}\text { Age, Intellectual disability, } \\
\text { Length of stay, Child year of } \\
\text { birth, Sex, Mother's } \\
\text { Indigenous status, SEIFA, } \\
\text { Health insurance, Mothers } \\
\text { age group, Rurality, Health } \\
\text { region, Birth defect. }\end{array}$ & $\begin{array}{l}\text { Reasons for dental } \\
\text { related hospital } \\
\text { admissions; } \\
\text { - Disorders of tooth } \\
\text { development and } \\
\text { eruption } 10.7 \% \\
\text { - Diseases of hard } \\
\text { tissues of teeth } \\
38.9 \% \\
\text { - Diseases of pulp and } \\
\text { periapical tissues } \\
5.9 \% \\
\text { - Gingival and } \\
\text { periodontal diseases } \\
4.4 \% \\
\text { - Dento-facial anomal- } \\
\text { ies including mal- } \\
\text { occlusion } 0.3 \% \\
\text { - Other diseases and } \\
\text { conditions of the } \\
\text { teeth and } \\
\text { supporting } \\
\text { structures } 1.3 \% \\
\text { - Diseases of the jaws } \\
\text { 1.8\% } \\
\text { - Diseases of the } \\
\text { salivary glands } 4.6 \% \\
\text { - Diseases of the oral } \\
\text { soft tissues } \\
\text { excluding lesions } \\
\text { specific } \\
\text { - for gingiva and } \\
\text { tongue } 29.4 \% \\
\text { - Diseases and other } \\
\text { conditions of the } \\
\text { tongue } 1.5 \% \\
\text { - Fitting and } \\
\text { adjustments of other } \\
\text { devices-orthodontic } \\
\text { devices } 0.4 \% \\
\text { - Special } \\
\text { investigations and } \\
\text { examination } 1.0 \% \\
\end{array}$ & $\begin{array}{l}\text { Male gender (OR 1.14), low } \\
\text { birth weight (OR 1.17), birth } \\
\text { defects (OR 1.74), intellectual } \\
\text { disability (OR 2.10), children } \\
\text { of indigenous mother (OR } \\
\text { 4.45), having public health } \\
\text { insurance (OR 1.29), and } \\
\text { rurality/remoteness (OR 2.29) } \\
\text { had significantly higher odds } \\
\text { of dental related hospital } \\
\text { admissions. } \\
\text { Least disadvantaged has } \\
\text { significantly lower risk of } \\
\text { dental related hospital } \\
\text { admission than most } \\
\text { disadvantaged (OR 0.58). }\end{array}$ \\
\hline $\begin{array}{l}\text { Verma et.al, } \\
2014[10] \\
\text { Tasmania }\end{array}$ & $\begin{array}{l}N=454 \\
0-86 \text { years } \\
\text { (mean age } \\
32 \text { ) }\end{array}$ & N/A & $\begin{array}{l}\text { Cross } \\
\text { Sectional } \\
\text { Retrospective }\end{array}$ & $\begin{array}{l}\text { Age, Gender, timing of } \\
\text { presentation }\end{array}$ & $\begin{array}{l}\text { Causes for attending } \\
\text { ED due to dental } \\
\text { related cause: } \\
\text { - Dental abscess } \\
37.2 \% \\
\text { - Toothache } 31.5 \% \\
\text { - Dental caries } 8.8 \% \\
\text { - Tooth fracture } 7.3 \% \\
\text { - Tooth avulsion or } \\
\text { loss } 6.8 \% \\
\text { - Gingivo-stomatitis } \\
\text { 4.6\% } \\
\text { - Aphthous ulcer } 3.1 \% \\
\text { - Temporomandibular } \\
\text { joint Disorder } 0.7 \%\end{array}$ & $\begin{array}{l}\text { Male (60.2\%) had more } \\
\text { dental presentation to ED } \\
\text { than female ( } 39.8 \%) \text {. } \\
\text { Individuals with ages } 26-30 \\
\text { years had highest dental } \\
\text { presentations in ER (17\%). } \\
\text { Average age of patients with } \\
\text { dental abscess (the most } \\
\text { common presentation) was } \\
36.59 \text { years. } \\
68 \% \text { of presentation were } \\
\text { out of business hours. }\end{array}$ \\
\hline $\begin{array}{l}\text { Alsharifet.al,2014 } \\
\text { [14] } \\
\text { WA }\end{array}$ & $\begin{array}{l}N=43,937 \\
0-14 \text { years }\end{array}$ & ICD 10 AM & $\begin{array}{l}\text { Cross } \\
\text { sectional } \\
\text { Retrospective }\end{array}$ & $\begin{array}{l}\text { Hospital area and type, Age, } \\
\text { gender, Indigenous status, } \\
\text { SEIFA, ARIA, Insurance status, } \\
\text { Length of stay }\end{array}$ & $\begin{array}{l}\text { Major categories of } \\
\text { dental related hospital } \\
\text { admissions: } \\
\text { - Dental caries 50\% } \\
\text { - Embedded and } \\
\text { Impacted teeth 14\% }\end{array}$ & $\begin{array}{l}5 \% \text { of total dental related } \\
\text { hospital admission for this } \\
\text { age group were indigenous } \\
\text { children. } \\
73 \% \text { admissions were in less } \\
\text { than } 9 \text { years old age group. }\end{array}$ \\
\hline
\end{tabular}


Table 3 Characteristics of studies and the summary of results (Continued)

\begin{tabular}{llll}
\hline Author, year, & $\begin{array}{l}\text { Number of } \\
\text { hospitalised }\end{array}$ & $\begin{array}{l}\text { Classification } \\
\text { ftate }\end{array}$ & Study design \\
episodes/ & of disease &
\end{tabular}

res

\begin{tabular}{ll} 
Summary of results & \\
\hline Reason for & Demographic factors \\
hospitalisation &
\end{tabular}

\begin{tabular}{|c|c|c|c|c|c|c|}
\hline & & & & & $\begin{array}{l}\text { - Pulp and periapical } \\
\text { tissue conditions } \\
11 \% \\
\text { - Developmental and } \\
\text { birth defects 5\% } \\
\text { - Dental Fractures 5\% } \\
\text { - Dentofacial } \\
\text { anomalies 4\% }\end{array}$ & $\begin{array}{l}\text { Rate of admission in children } \\
\text { age 5-9years increased } \\
\text { significantly as compared to } \\
\text { age group 0-4 years in } 2009 \text {. } \\
\text { Non indigenous children } \\
\text { were more likely to be } \\
\text { admitted for all dental causes } \\
\text { except pulp and periapical } \\
\text { conditions, and dental } \\
\text { fractures. } \\
\text { Males, least disadvantaged, } \\
\text { high accessibility and } \\
\text { uninsured children had } \\
\text { significantly more dental } \\
\text { admissions ( } p<.0 .001) \text {. } \\
\text { The dental related hospital } \\
\text { admissions were more in } \\
\text { public }(p<0.001) \text { and } \\
\text { metropolitan hospitals. }\end{array}$ \\
\hline $\begin{array}{l}\text { Kruger et.al, } \\
2015 \text { [20] } \\
\text { WA }\end{array}$ & $\begin{array}{l}N=65,005 \\
0-75+\text { years }\end{array}$ & ICD-10 AM & $\begin{array}{l}\text { Cross } \\
\text { Sectional } \\
\text { Retrospective }\end{array}$ & $\begin{array}{l}\text { Age, gender, ethnicity, SEIFA, } \\
\text { Indigenous status, ARIA, AR- } \\
\text { DRG, Income, Housing, Edu- } \\
\text { cation, Employment, Family } \\
\text { structure, Disability, } \\
\text { Transport. }\end{array}$ & $\begin{array}{l}\text { The rate of } \\
\text { hospitalisation due to } \\
\text { preventable dental } \\
\text { cause has been } \\
\text { increasing significantly } \\
\text { over the years. } \\
\text { - Dental caries } 53 \% \\
\text { - Other disease of } \\
\text { hard tissue of teeth } \\
1.2 \% \\
\text { - Pulp and periapical } \\
\text { tissue } 14.3 \% \\
\text { - Gingivitis and } \\
\text { periodontal disease } \\
5.1 \% \\
\text { - Other gingival and } \\
\text { edentulous alveolar } \\
\text { ridge } 0.6 \% \\
\text { - Other disorders } \\
\text { teeth and } \\
\text { supporting } \\
\text { structures } 18.1 \% \\
\text { - Cysts of oral region } \\
1.9 \% \\
\text { - Stomatitis and } \\
\text { related lesions } 2.2 \% \\
\text { - Other diseases lip } \\
\text { and oral mucosa } \\
3.6 \%\end{array}$ & $\begin{array}{l}3.2 \text { per } 1000 \text { people were } \\
\text { admitted to hospital due to } \\
\text { oral condition. } \\
\text { Females, aboriginals, most } \\
\text { disadvantaged, highly } \\
\text { accessible people had more } \\
\text { hospital admission due to } \\
\text { oral conditions. }\end{array}$ \\
\hline $\begin{array}{l}\text { Kruger \& } \\
\text { Tennant } 2016 \\
\text { [19] } \\
\text { WA }\end{array}$ & $\begin{array}{l}\mathrm{N}=11,608 \\
65 \text { years and } \\
\text { older }\end{array}$ & ICD-10 AM & $\begin{array}{l}\text { Cross } \\
\text { sectional } \\
\text { Retrospective }\end{array}$ & $\begin{array}{l}\text { Age, gender, ethnicity, SEIFA, } \\
\text { Indigenous status, ARIA, AR- } \\
\text { DRG, Income, Housing, Edu- } \\
\text { cation, Employment, Family } \\
\text { structure, Disability, } \\
\text { Transport. }\end{array}$ & $\begin{array}{l}\text { Causes of dental } \\
\text { related hospital } \\
\text { admission: } \\
\text { - Malignant } \\
\text { neoplasms } 16.6 \% \\
\text { - Dental caries 15.4\% } \\
\text { - Other disorders of } \\
\text { teeth and } \\
\text { supporting } \\
\text { structures } 14.3 \% \\
\text { - Other diseases of } \\
\text { the jaws } 11.3 \% \\
\text { - Fractures of the } \\
\text { teeth, nasal bone, } \\
\text { palate, lower facial } \\
\text { bones } 5.4 \%\end{array}$ & $\begin{array}{l}\text { Most patients for dental } \\
\text { related hospital admissions } \\
\text { were from least } \\
\text { disadvantaged ( } 27.9 \%, \text { OR } \\
60.04 \text { ) and accessible areas } \\
(16.4 \%, \text { OR 10.58). } \\
\text { Age } 75-79 \text { years (OR } 4.7 \mathrm{Cl} \\
4.57-4.98) \text {, Males (OR 5.82, Cl } \\
5.67-6.21) \text { and Aboriginals } \\
\text { (OR 9.38, Cl 7.82-10.94) had } \\
\text { significantly higher rate of } \\
\text { hospitalisation }(p<0.05) \text {. }\end{array}$ \\
\hline
\end{tabular}


Table 3 Characteristics of studies and the summary of results (Continued)

\begin{tabular}{|c|c|c|c|c|c|c|}
\hline \multirow{2}{*}{$\begin{array}{l}\text { Author, year, } \\
\text { state }\end{array}$} & \multirow{2}{*}{$\begin{array}{l}\text { Number of } \\
\text { hospitalised } \\
\text { episodes/ } \\
\text { age }\end{array}$} & \multirow{2}{*}{$\begin{array}{l}\text { Classification } \\
\text { for diagnosis } \\
\text { of disease }\end{array}$} & \multirow[t]{2}{*}{ Study design } & \multirow[t]{2}{*}{ Covariates } & \multicolumn{2}{|l|}{ Summary of results } \\
\hline & & & & & $\begin{array}{l}\text { Reason for } \\
\text { hospitalisation }\end{array}$ & Demographic factors \\
\hline & & & & & $\begin{array}{l}\text { - Benign neoplasms } \\
5.4 \% \\
\text { - Embedded and } \\
\text { impacted teeth } 5.1 \% \\
\text { - Diseases of salivary } \\
\text { glands } 4.5 \% \\
\text { - Diseases of pulp and } \\
\text { periapical tissues } \\
3.8 \% \\
\text { - Other disease of lip } \\
\text { and oral mucosa } \\
3.1 \% \\
\text { - Stomatitis and } \\
\text { related lesions } 2.3 \% \\
\text { - Diseases of the } \\
\text { tongue } 1.9 \% \\
\text { - Others } 10.8 \%\end{array}$ & \\
\hline $\begin{array}{l}\text { Kruger et.al, } \\
2016 \text { [18] } \\
\text { WA }\end{array}$ & $\begin{array}{l}N=131,509 \\
18 \text { years and } \\
\text { older }\end{array}$ & ICD-10 AM & $\begin{array}{l}\text { Cross } \\
\text { sectional } \\
\text { Retrospective }\end{array}$ & $\begin{array}{l}\text { Age, gender, ethnicity, SEIFA, } \\
\text { Indigenous status, ARIA, AR- } \\
\text { DRG, Income, Housing, Edu- } \\
\text { cation, Employment, Family } \\
\text { structure, Disability, } \\
\text { Transport. }\end{array}$ & $\begin{array}{l}\text { Causes of dental } \\
\text { related hospital } \\
\text { admissions: } \\
\text { - Embedded and } \\
\text { impacted teeth } \\
48.9 \% \\
\text { - Dental caries 9.0\% } \\
\text { - Other disorders of } \\
\text { teeth and } \\
\text { supporting } \\
\text { structures } 8.5 \% \\
\text { - Jaw fractures } \\
\text { (maxillary and } \\
\text { mandibular) } 4.9 \% \\
\text { - Fractures of teeth, } \\
\text { nasal bone, palate, } \\
\text { lower facial bones } \\
4.3 \% \\
\text { - Malignant } \\
\text { neoplasms 3.9\% } \\
\text { - Diseases of pulp and } \\
\text { periapical tissues } \\
3.4 \% \\
\text { - Other diseases of } \\
\text { jaws 3.2\% } \\
\text { - Dentofacial } \\
\text { anomalies, including } \\
\text { malocclusion 2.6\% } \\
\text { - Gingivitis and } \\
\text { periodontal diseases } \\
2.3 \% \\
\text { - Others } 8.9 \%\end{array}$ & $\begin{array}{l}48 \% \text { were male and } 2.8 \% \\
\text { were aboriginal descent. } \\
\text { Rates of admissions were } \\
\text { significantly higher in } \\
\text { aboriginal as compared to } \\
\text { non-aboriginal during } 10 \text { year } \\
\text { period ( } p<0.05 \text { ) } \\
\text { The rate of admission was } \\
\text { highest for age group } 18-29 \\
\text { years for both aboriginal and } \\
\text { non-aboriginal. }\end{array}$ \\
\hline
\end{tabular}

ICPC International Classification of Primary Care, AR-DRD Australian Refined Diagnosis Related Groups, ICD International Classification of Diseases IRSD Index of relative socio economic disadvantage, ARIA Accessibility/Remoteness Index of Australia, DRG Diagnostic Related Group, SEIFA Socio-Economic Indexes for Areas, WA Western Australia

The main limitation of this systematic review was the small number of published studies investigating PDHAs in Australia. Of the included studies, almost all were from one state of Australia indicating that further research is needed in PDHA across Australia. Databases with this potential information are available in each state. Investigators need to be encouraged to access, analyse and publish this information as an important preventative and public health issue. There was a high level of heterogeneity observed among the 11 included studies. This limited the authors from conducting a meta-analysis. The studies had a wide variation among two main factors: (i) age; and (ii) the ICD definitions used to define dental conditions that could have been employed in a meta-analysis to predict the effect size of the PDHA across the studies.

PDHA are expensive and they may be reduced by the impartial distribution of public dental clinics [32]. The extension of dental services into areas currently not receiving 


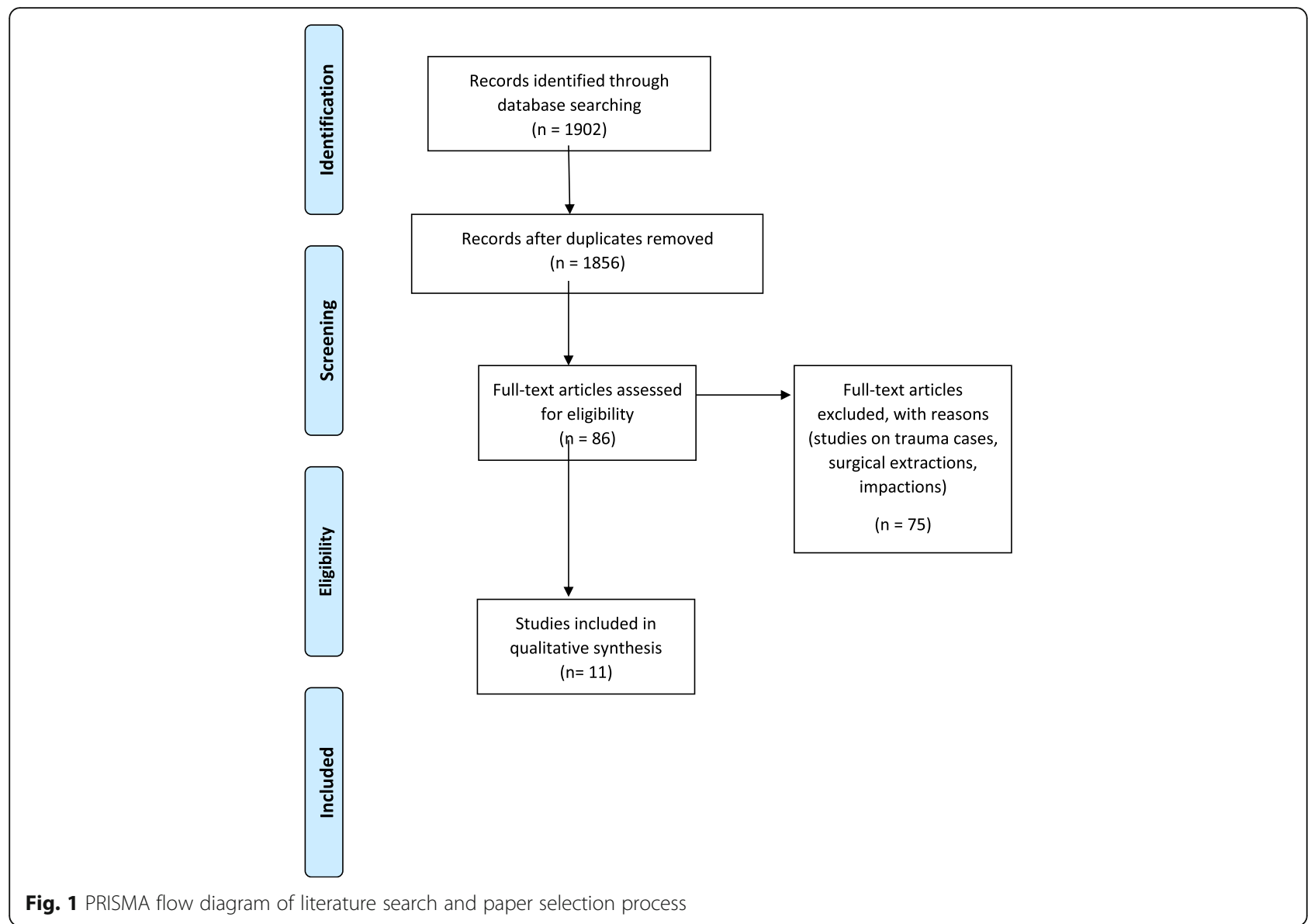

dental care will not only reduce cost associated with PDHA, but will improve access to oral health care. A periodic audit of PDHA is needed to mobilise government policy-makers and dental service providers for delivery of a fair and effective dental service for all Australians throughout their life course.

\section{Conclusion}

Dental caries is the most common cause of PDHA based on the included studies. As most of studies included are from WA, there is the need of Australia wide research to represent real scenario of PDHA.

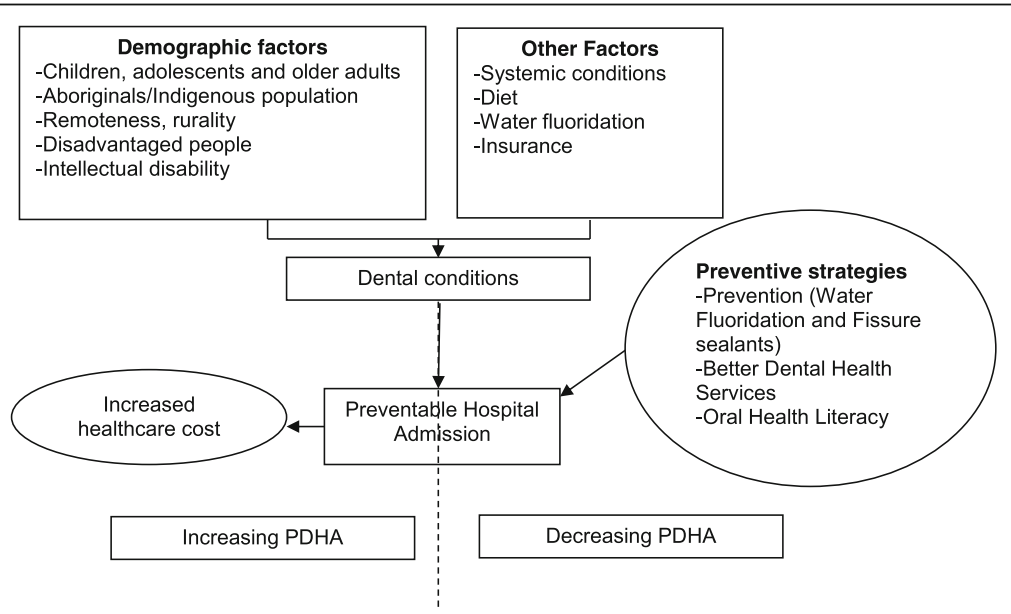

Fig. 2 Schematic diagram of preventable dental hospital admission: risk factors and preventive strategies 


\section{Abbreviations}

ARDRD: Australian Refined Diagnosis Related Groups; ARIA: Accessibility/ Remoteness Index of Australia; DRG: Diagnostic Related Group; ICD: International Classification of Diseases; ICPC: International Classification of Primary Care; IRSD: Index of relative socio economic disadvantage; MMAT: Mixed Method Appraisal Tool; NCOHS: National Child Oral Health Survey; PDHA: Preventable Dental Hospital Admissions; PHA: Preventable Hospital Admissions; PICO: Population Intervention Comparator Outcome; PRISMA: Preferred Reporting Items for Systematic Reviews and MetaAnalyses; SEIFA: Socio-Economic Indexes for Areas; WA: Western Australia; WAHMDS: Western Australian Hospital Morbidity Data System

\section{Acknowledgements}

We would like to thank Dr. Diana Godwin for her feedback on earlier versions of the manuscript.

1. Health Practitioner Research Development Program, Centre for Rural Health, University of Tasmania

2. Australian Government Research Training Program Scholarship Department of Education and Training.

3. Translating Research into Practice Fellowship, National Health and Medical Research Council.

\section{Funding}

Health Practitioner Research Development Program, Centre for Rural Health, University of Tasmania supported the primary author Abhinav Acharya towards conducting this research project. Australian Government Research Training Program Scholarship Department of Education and Training supported Shahrukh Khan in contributing towards this systematic review research design, concept and drafting. Translating Research into Practice Fellowship, National Health and Medical Research Council supported Associate Professor Leonard Crocombe towards allocation of his time in supervising this research project.

\section{Availability of data and materials}

Not applicable.

\section{Authors' contributions}

AA is the lead author of this review. He was involved in analysis, critical review and drafting of the manuscript. SK was involved in conception of the project, critical review of papers and drafting of the manuscript. LC SB were involved in the conception of the project and peer review of the manuscript. $\mathrm{HH}$ was involved in critical appraisal and peer review of the manuscript. LG provided suggestions towards refining the aims and peer reviewed the work. All authors read and approved the final manuscript.

\section{Ethics approval and consent to participate}

Not applicable.

\section{Consent for publication}

Not applicable.

\section{Competing interests}

The authors declare that they have no competing interests.

\section{Publisher's Note}

Springer Nature remains neutral with regard to jurisdictional claims in published maps and institutional affiliations.

\footnotetext{
Author details

${ }^{1}$ Centre for Rural Health, College of Health and Medicine, University of Tasmania, Hobart, Tasmania, Australia. ${ }^{2}$ Centre for Rural Health, College of Health and Medicine, University of Tasmania, Launceston, Tasmania, Australia. ${ }^{3}$ School of Medicine, College of Health and Medicine, University of Tasmania, Hobart, Tasmania, Australia. ${ }^{4}$ Wicking Dementia Research and Education Centre, College of Health and Medicine, University of Tasmania, Hobart, Tasmania, Australia.
}

Received: 21 March 2018 Accepted: 19 November 2018 Published online: 03 December 2018

\section{References}

1. AlHW. Australian hospital statistics 2011-12. Canberra, ACT, Australia: ABS; 2013. Contract No.: Catalogue number HSE 134.

2. Schumacher JR, Hall AG, Davis TC, Arnold CL, Bennett RD, Wolf MS, et al. Potentially preventable use of emergency services: the role of low health literacy. Med Care. 2013;51(8):654.

3. AlHW. National Healthcare Agreement: selected potentially preventable hospitalisations, 2016. Canberra: AlHW; 2016

4. Spencer J, Sendziuk P, Slade G, Harford J. Australia's dental generations: the National Survey of adult Oral health 2004-06. Canberra: Australian institute of health and welfare; 2007.

5. Slade G, Sanders A, Do L, Roberts-Thomson K, Spencer A. Effects of fluoridated drinking water on dental caries in Australian adults. J Dent Res. 2013;92:376-82.

6. Vecchio N, Chung RY-M, Johnson N. The association between state funding and utilization of dental services: a case for a universal dental scheme. Griffith University, Australia. 2015.

7. LG Do LL, DH Ha, KF Roberts-Thomson, S Chrisopoulos, JM Armfield and AJ Spencer. Trends in child oral health in Australia, Oral health of Australian children: the National Child Oral Health Study 2012-14. Adelaide, Australia: University of Adelaide; 2016.

8. Rachel K. Potentially avoidable hospitalisations in Australia: causes for hospitalisations and primary health care interventions Australia, Australia/ Oceania: Primary Health Care Research and Information Service; 2012.

9. Chrisopoulos S, Harford JE, Ellershaw A. Oral health and dental care in Australia: key facts and figures 2015. Canberra: AlHW; 2016.

10. Pluye P, Robert E, Cargo M, Bartlett G, O'Cathain A, Griffiths F, et al. Mixed methods appraisal tool (MMAT) version 2011. Proposal: a mixed methods appraisal tool for systematic mixed studies reviews, McGill University, Department of Family Medicine. 2011.

11. Verma S, Chambers I. Dental emergencies presenting to a general hospital emergency department in Hobart, Australia. Aust Dent J. 2014;59:329-33.

12. Slack-Smith L, Colvin L, Leonard H, Kilpatrick N, Read A, Messer LB. Dental admissions in children under two years - a total-population investigation. Child Care Health Dev. 2012:39:253-9.

13. Slack-Smith L, Colvin L, Leonard H, Kilpatrick N, Bower C, Brearley Messer L. Factors associated with dental admissions for children aged under 5 years in Western Australia. Arch Dis Child. 2009;94:517-23.

14. Slack-Smith LM, Read AW, Colvin LJ, Leonard H, Kilpatrick N, McAullay D, et al. Total population investigation of dental hospitalizations in indigenous children under five years in Western Australia using linked data. Aust Dent J. 2011;56:358-64.

15. Alsharif AT, Kruger E, Tennant M. Dental hospitalization trends in Western Australian children under the age of 15 years: a decade of population-based study. Int J Paediatr Dent. 2014;25:35-42.

16. Kruger E, Dyson K Tennant M. Hospitalization of Western Australian children for oral health related conditions: a 5-8 year follow-up. Aust Dent J. 2006;51:231-6.

17. Tennant M, Namjoshi D, Silva D, Codde J. Oral health and hospitalization in Western Australian children. Aust Dent J. 2000;45:204-7.

18. Smith $\mathrm{K}$, Kruger $\mathrm{E}$, Tennant M. A four-year retrospective study of adult hospitalization for oral diseases in Western Australia. Aust Dent J. 2006;51:312-7.

19. Kruger E, Tennant M. Ten years of hospitalisation for oral health-related conditions in Western Australia: an unjust dichotomy. Aust J Prim Health. 2016;22:153-8.

20. Kruger E, Tennant M. Hospital admissions of older people for oral healthrelated conditions: implications for the future. Gerodontology. 2016;33:490-8.

21. Kruger E, Tennant M. Potentially preventable hospital separations related to oral health: a 10-year analysis. Aust Dent J. 2015;60:205-11.

22. Diagnosis LY. Prevention strategies for dental caries. J Lifestyle Med. 2013;3(2):107.

23. Petersen $P E$, Lennon MA. Effective use of fluorides for the prevention of dental caries in the 21st century: the WHO approach. Community Dent Oral Epidemiol. 2004;32:319-21.

24. Slade GD, Spencer AJ, Roberts-Thomson KF. Australia's dental generations: The national survey of adult oral health. Canberra: Australian Institute of Health and Welfare (Dental Statistics and Research Series No. 34): Cat. no. DEN 165; 2007. Contract No.; 2007.

25. Jin L, Lamster I, Greenspan J, Pitts N, Scully C, Warnakulasuriya S. Global burden of oral diseases: emerging concepts, management and interplay with systemic health. Oral Dis. 2016;22:609-19. 
26. Whyman RA, Mahoney EK, Morrison D, Stanley J. Potentially preventable admissions to New Zealand public hospitals for dental care: a 20-year review. Community Dent Oral Epidemiol. 2014;42:234-44.

27. Glick M, Monteiro da Silva O, Seeberger GK, Xu T, Pucca G, Williams DM, et al. FDI vision 2020: shaping the future of oral health. Int Dent J. 2012;62:278-91.

28. Abdelhafied DH, Kruger E, Tenant M. Projections of the incidence of pharyngeal, tongue and parotid gland cancer in Western Australia. AustralAsian. J Cancer. 2014;13:31-6.

29. Abreu LP, Kruger E, Tennant M. Oral cancer in Western Australia, 1982-2006: a retrospective epidemiological study. J Oral Pathol Med. 2010;39:376-81.

30. Khan S, Barrington G, Bettiol S, Barnett T, Crocombe L. Is overweight/obesity a risk factor for periodontitis in young adults and adolescents?: a systematic review. Obes Rev. 2018;19:852-83.

31. Khan S, Taimur K, Awan KH. Chronic periodontitis and smoking. Prevalence and dose-response relationship. Saudi Med J. 2016;37:889-94.

32. Coles E, Kruger E, Anjinin AA, Tennant M. The urban dental index: a method for measuring and mapping dental health disparities across urban areas. J Urban Health. 2017;94:211-9.

Ready to submit your research? Choose BMC and benefit from:

- fast, convenient online submission

- thorough peer review by experienced researchers in your field

- rapid publication on acceptance

- support for research data, including large and complex data types

- gold Open Access which fosters wider collaboration and increased citations

- maximum visibility for your research: over $100 \mathrm{M}$ website views per year

At $\mathrm{BMC}$, research is always in progress.

Learn more biomedcentral.com/submissions 